ISSN 0103-8478

\title{
Critical yield-point model to estimate damage caused by brown spot and powdery mildew in barley
}

Modelo do ponto crítico para estimar danos causados pela mancha-marrom e oídio em cevada

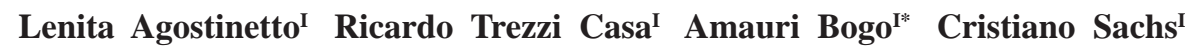 \\ Erlei Melo Reis" Paulo Roberto Kuhnem III
}

\section{ABSTRACT}

Barley (Hordeum vulgaris L.) is the second most important winter crop in Southern Brazil. The excessive rainfall in this region during the crop-growing season increases the frequency and intensity of foliar fungal diseases. The research aimed to determine the damage function equations (DFE) for the multiple pathosystem of barley brown spot and powdery mildew based on the relationship between grain yield and diseases intensity at different 'BRS Cauê' cultivar growth stages (GS) during 2009 and 2010 growing seasons in Southern Brazil. The experiments were arranged in a randomized complete block design with nine treatments and four replicates. The disease gradients were generated by strobilurins and triazols fungicides rates and number of applications on barley cv. Cauê. The fungicide applications and disease incidence and severity assessments were performed at the 22, 31, 39, 45 and 56 plant GS. The DFE were obtained by variance analysis and linear regression between grain yield and diseases intensity. Significant and negative DFE were obtained and the damage coefficients (DC) varied from 29.48 to 100.08 (2009) and from 36.08 to $113.57 \mathrm{~kg} \mathrm{ha}^{-1}$ (2010) for incidence, and from 219.5 to $6,276.6$ (2009) and 102.3 to $5,292.5 \mathrm{~kg} \mathrm{ha}^{-1}$ (2010) for severity. The largest damage coefficients were obtained when diseases assessments were made on GS 22 and 31 on both growing seasons evaluated. DFE were used to calculate the economic damage threshold (EDT) as a criterion to indicate the fungicide application moment to control the diseases in cultivars similar to 'BRS Cauê' in Southern Brazil.

Key words: Bipolaris sorokiniana, Blumeria graminis $f$. $s p$. hordei, Hordeum vulgare, multiple pathosystem, economic damage threshold.

RESUMO

A cevada (Hordeum vulgaris L.) é a segunda mais importante cultura de inverno no Sul do Brasil. Nessa região, o excesso de chuvas durante a estação de crescimento da cultura favorece o aumento na frequência e intensidade de doenças foliares. O trabalho objetivou determinar as equações de função de dano (EFD) para o patossistema múltiplo mancha-marrom $e$ oídio da cevada pela relação entre rendimento de grãos $e$ intensidade foliar das doenças em diferentes estádios fenológicos da cultivar de cevada 'BRS Cauê', nas safras 2009 e 2010 no sul do Brasil. O delineamento foi em blocos casualizados com nove tratamentos e quatro repetições. Os tratamentos foram constituídos de diferentes doses e número de aplicações dos fungicidas triazóis e estrobilurinas para gerar os gradientes de intensidade das doenças. As aplicações de fungicidas e as avaliações da incidência e severidade foliar foram realizadas nos estádios fenológicos (EF) 22, 31, 39, 45 e 56. As equações foram obtidas pela análise de variância e regressão linear entre rendimento de grãos e intensidade das doenças. As EFD foram significativas $e$ negativas e os coeficientes de danos variaram de 29,48 a 100,08kg ha $a^{-1}$ (2009) e 36,08 a 113,57 $\mathrm{kg} \mathrm{ha}^{-1}$ (2010) para a incidência e de 219,5 a 6.276,6kg ha-1 (2009) e 102,3 a 5.292,5kg ha-1 (2010). Os maiores coeficientes de dano foram obtidos nos estádios EF 22 e 31em ambas as safras. As EFD foram usadas para calcular o limiar de dano econômico, que é um critério que indica o correto momento de aplicação de fungicidas para o controle das doenças em cultivares similares a 'BRS Cauê' no sul do Brasil.

Palavras-chave: Bipolaris sorokiniana, Blumeria graminis $f$. sp. hordei, Hordeum vulgare, patossistema múltiplo, limiar de dano econômico.

\section{INTRODUCTION}

Barley (Hordeum vulgaris L.) is the fourth most important crop in the world after maize, wheat and rice (MEUSSDOERFFER, 2009). Barley

\footnotetext{
'Programa de Pós-graduação em Produção Vegetal, Universidade do Estado de Santa Catarina (UDESC), Av. Luis de Camões, 2090, 88520-000, Lages, SC, Brasil. E-mail: amauribogo@udesc.br. *Autor para correspondência.

"Departamento de Fitopatologia, Universidade de Passo Fundo (UPF), Passo Fundo, RS, Brasil.

IIIDepartamento de Fitossanidade, Universidade Federal Rio Grande do Sul (UFRGS), Porto Alegre, RS, Brasil. Received 12.07.12 Approved 12.02.13 Returned by the author 03.19.14 CR-2012-1244.R1
} 
is cultivated as a summer crop in temperate areas and as a winter crop in tropical areas for malt production. Brazil is one of the largest barley-importing countries, producing only $30 \%$ of the national brewing industry's demand. Brazil's 2011 barley production was approximately 305 thousand tons in 88,4 thousand ha (CONAB, 2012).

The excessive rainfall in Southern Brazil during the crop-growing season increases the frequency and intensity of foliar fungal diseases (REIS \& CASA, 2007). The main foliar fungal diseases are brown spot (Bipolaris sorokiniana (Sacc.) Shoemaker), net blotch (Drechslera teres (Sacc.) Shoem.) and powdery mildew (Blumeria graminis DC. f. sp. hordei Em. Marchal.). These diseases intensities depend on cultivar susceptibility, crop systems, tillage practices and environment conditions (MATRHE, 1997). Barley diseases can be controlled by genetic resistance and management practices such as seed treatment, aerial fungicide application, seeding date and seeding rate, balanced fertility, weeds and volunteer crop-plant control and harvest management (MATRHE, 1997; KUMAR et al., 2002). Aerial fungicide applications have been one of the most important strategies in some countries, such as Brazil, to control most diseases in winter cereal crops (PICININI et al., 1996; LENZ et al., 2011).

The indicative criteria for the timing of aerial fungicide applications to barley crops are not yet clearly based on the research data. Normally, the fungicide applications are preventive and/or performed according to the crop growth stage (REIS \& CASA, 2007). The indicative criteria to control barley brown spot and powdery mildew based on disease intensity are $3 \%$ foliar severity or $20 \%$ foliar incidence and 2-3\% foliar severity, respectively (REUNIÃO, 2011). Fungicide applications aiming higher yields without considering economic and technical criteria like disease intensity and damage, and cost and efficiency of disease control can increase production costs. There is a certain amount of information regarding fungicide application based only on disease intensity associated to losses, control costs or fungicide efficiency. These factors can induce unnecessary or late fungicide applications when the disease intensity has already overcome the economic damage threshold (EDT) (CASA et al., 2009).

The EDT is the term used to define the disease intensity that can cause losses equal to the control cost, and it consists of rational and scientific indicative criterion for fungicides' applications (REIS
\& CASA, 2007). In Brazil, there are many barley crop damage function equations (DFE) for simple pathosystems, such as powdery mildew (REIS et al., 2002), brown spot (REIS \& CASA, 2007) and net blotch (REIS et al., 1999). These equations were obtained for isolated and independent diseases without considering the situation of multiple pathosystem such as when more than one disease affects a crop simultaneously. In Brazil, barley is normally grows in the non-tillage system after wheat or oat (Avena sativa L.) rotation, increasing the brown spot occurrence because the pathogen can survive in the plant debris of the previous crop (MATHRE, 1997; REIS \& CASA, 2007). Many epidemiological models, such as the critical yield-point model, have been used to estimate crop DFE for plant diseases. The criticalpoint model is particularly useful for identifying a specific host plant growth stage in which the disease intensity is closely correlated with the future crop damage (BERGAMIN FILHO \& AMORIM, 1996). From the DFE, damage coefficients are obtained, and they vary according to each plant species growth stages and cultivars (REIS \& CASA, 2007).

The objectives of this study were (i) to estimate the DFE for the multiple pathosystem of barley brown spot and powdery mildew using the critical-point and experimental parcel models relating the disease intensity to the grain yield, and (ii) to determine the EDT using the model-generated damage coefficient from the DFE.

\section{MATERIAL AND METHODS}

The experiments were carried out during the 2009 and 2010 growing seasons at the NBN Seeds Company in the Muitos Capões Municipality in the State of Rio Grande do Sul, Southern Brazil (28 ${ }^{\circ} 15^{\prime} 51$ $\mathrm{S}$ and $\left.51^{\circ} 10^{\prime} 54 \mathrm{~W}\right)$, at an $937 \mathrm{~m}$ above sea level. The experiments were conducted using the barley cultivar 'BRS Cauê', which is susceptible to brown spot and powdery mildew and is widely cultivated, due to its high productivity, agronomic type and malt quality (REUNIÃO, 2011). The climate of the region is humid mesothermic $(\mathrm{Cfb})$, according to the Köppen classification. Higher rainfall in Muitos Capões occurs from October to March, and during this period, the average monthly precipitation is approximately $166 \mathrm{~mm}$. The region's soil has a basaltic rock origin, classified as brown latosol aluminic cambic (Oxisol class A) with clay texture (EMBRAPA, 1999).

The experiments were carried out in a notillage area with oat crop rotation system and soybean succession. Sowing dates were on June $27^{\text {th }} 2009$ 
and June $12^{\text {th }} 2010$, and the experimental units were composed of 380 plants per $\mathrm{m}^{2}$ density, spaced $0.17 \mathrm{~m}$ between rows. The seeds were treated with $100 \mathrm{~mL}$ iprodione (Rovral), $80 \mathrm{~mL}$ carbendazim (Portero) and $60 \mathrm{~mL}$ imidacloprid (Gaucho) per $100 \mathrm{~kg}$ of seeds. The soil was fertilized with $204 \mathrm{~kg} \mathrm{ha}^{-1}$ of MAP $(11 \%$ of $\mathrm{N}$ and $52 \%$ of $\left.\mathrm{P}_{2} \mathrm{O}_{5}\right)$ and $187 \mathrm{~kg} \mathrm{ha}^{-1}$ of $\mathrm{KCl}(60 \%$ of $\mathrm{K}_{2} \mathrm{O}$ ). Insect control (caterpillars and aphids) was performed using $30 \mathrm{~mL} \mathrm{ha}^{-1}$ triflumuron (Certero) and $500 \mathrm{~mL} \mathrm{ha}^{-1}$ imidacloprid + betaciflutrin (Connect), and weed control was achieved using $70 \mathrm{~g} \mathrm{ha}^{-1}$ iodosulfuron-methyl (Hussar).

The experiments were arranged in a randomized complete block design with nine treatments and four replicative. Each plot had an experimental unit area of $5.0 \times 2.5 \mathrm{~m}$. To generate the disease gradients, strobilurin and triazol fungicide rates (one half and full recommended rates) and numbers of fungicides sprays (once, twice, third and fourth) were applied, according to REIS et al., (2000, 2002, 2007, 2008), BOHATCHUK et al. (2008) and NERBASS et al. (2010). The fungicide applications were performed at the plant GS 22 (Main shoot and 2 tillers), GS 31 (Swelling 1st node detectable), GS 39 (Flag leaf ligule just visible), GS 45 (Full-boot, boot above ligule of 2nd last leaf) and GS 56 (50\% of spikes visible), according to the diagrammatic scale of ZADOKS et al. (1974). Spraying was performed at 21 days intervals using a knapsack atomizer with $\mathrm{CO}_{2}$-generated pressure, a $2.0 \mathrm{~m}$-wide boom and a delivered volume of $200 \mathrm{~L} \mathrm{ha}^{-1}$.

The methodology used to obtain the disease gradients to estimate yield loss was the experimental plot method, using the critical-point model described by BERGAMIN FILHO \& AMORIM (1996). The critical-point model is particularly useful when it can identify a specific plant growth stage in which disease intensity is most closely correlated with the future damage. Thus, in practice, a simple model may be applied to estimate the damage caused to the host by a specific disease in function of the host's GS and disease intensity. This model is represented by the equation: $y=b_{0}+b_{1} x$. Where, ' $y$ ' represent the crop productivity rates and ' $\mathrm{x}$ ' represent the disease intensity rates (incidence/severity) of the host's growth stage (BERGAMIN FILHO \& AMORIM, 1996).

The brown spot and powdery mildew disease incidence and severity were assessed in ten tillers of ten plants per plot, which were sampled randomly at the five different plant GS 22 (main shoot and 2 tillers), 31 (swelling 1st node detectable), 39 (Flag leaf ligule just visible), 45 (Full-boot, boot above ligule of 2 nd last leaf) and 56 (60\% of spikes visible). The incidence of the diseases was defined by number of leaves with diseases symptoms divided by the total number of leaves evaluated. The diseases severity was assigned according to the wheat leaf spot diagrammatic scale of JAMES (1971). Distrain applicative of TOMERLIN \& HOWELL (1998) was used to train the raters. Plants from the central rows of each plot were harvested manually and threshed and cleaned by a stationary machine. Grain yield was expressed in $\mathrm{kg} \mathrm{ha}^{-1}$.

The plots yield rates were submitted to mathematical model of presupposition test followed by variance analysis $(\mathrm{P} \leq 0.05)$. The cultivar, plant GS and growing season interaction were significant by F-test $(\mathrm{P} \leq 0.05)$ and consequently, linear regression analysis among diseases intensities (independent variable) and grains yields (dependent variable) was conducted using Statistical Analysis System $\left(\mathrm{SAS}^{\circledR}\right)$ version 9.1, generating the DFE for each plant GS and growing seasons. The damage coefficients were obtained from the DFE, represented by ' $b_{0}$ ' of the equation $y=b_{0}+b_{1} x$ described previously. The linear regression used was due to the critical-point model adopted and the DFE was calculated according to REIS et al. (2001) by the following equation:

\section{$\mathrm{I}=\mathrm{Cc} /(\mathrm{Bp} \times \mathrm{Dc}) \times \mathrm{Ce}$}

Where $\mathrm{I}=$ foliar disease incidence, $\mathrm{Cc}=$ fungicide control cost ha ${ }^{-1}, \mathrm{Bp}=$ barley commercial grain price, $\mathrm{Dc}=$ damage coefficient from the DFE and $\mathrm{Ce}=$ fungicide control efficiency compared among severity of the control and 4 replicates treatments.

\section{RESULTS AND DISCUSSION}

The brown spot and powdery mildew intensities were similar during both 2009 and 2010 growing seasons, occurring predominant between the barley GS 22 and 45 ( tillering and heading). The low variation of climatic condition between both growing seasons was responsible for these results, where the average temperature and rainfall during both growing seasons were $26^{\circ} \mathrm{C}$ and $1.113 \mathrm{~mm}$, respectively (AGRITEMPO, 2012). In neither growing seasons leaf rust and net blotch were recorded.

Five incidence and severity DFE were generated for the 2009 and 2010 growing seasons with their respective coefficients of determination $\left(\mathrm{R}^{2}\right)$, totaling 20 linear equations (Figure 1 and 2). All damage function equations were significant $(\mathrm{P}<0.05)$ and negative, where the increase of diseases symptoms 


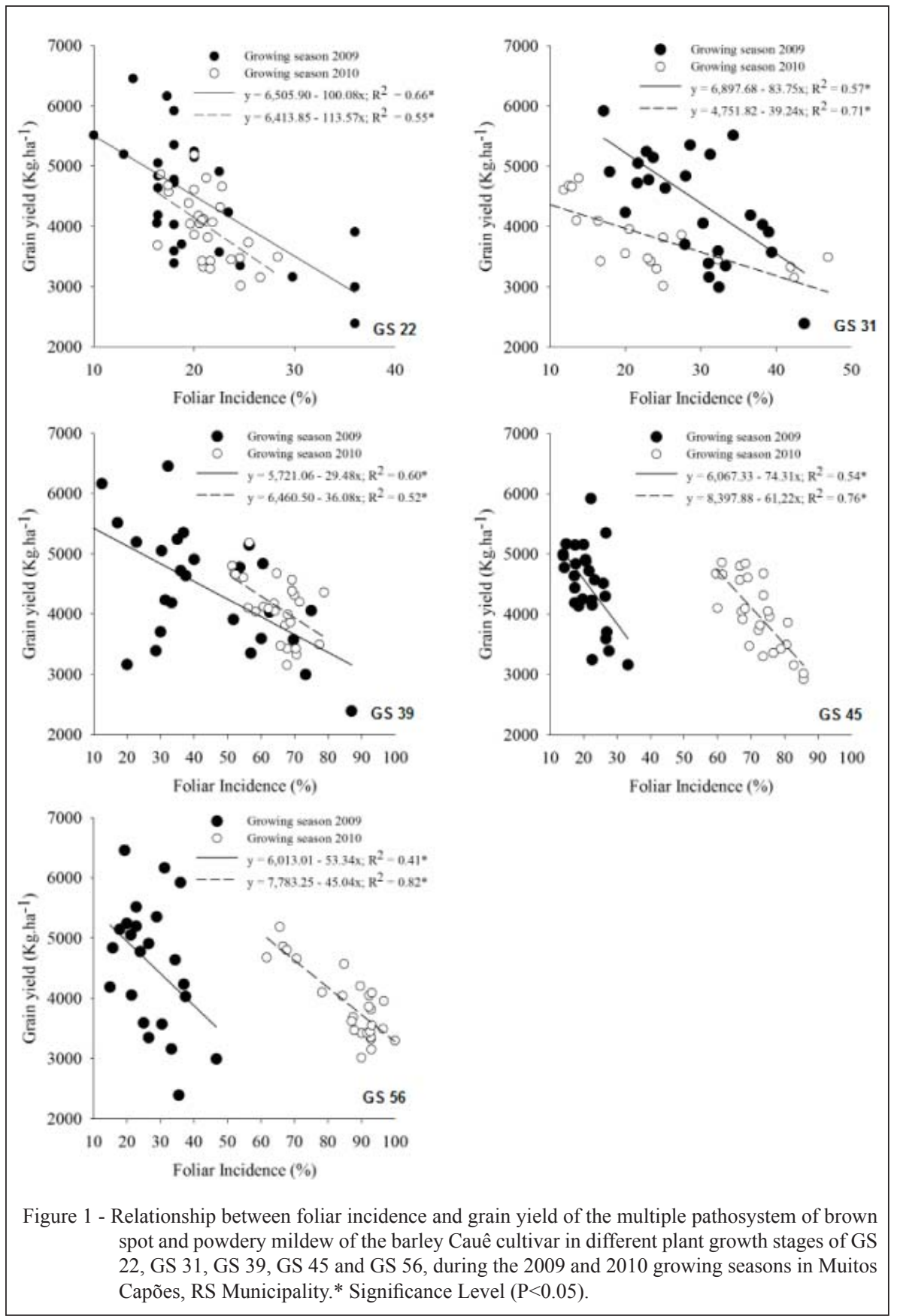

reduced the grains yield according to the GS. DFE have been described for simple pathosystems in barley like brown spot for cv. BR-2 (REIS \& CASA, 2007) and for powdery mildew for $\mathrm{cv}$. Antarctica-5 (REIS et al., 2002). These equations were obtained for isolated and independent diseases without considering the situation of multiple pathosystems which consider more than one disease occurring simultaneously. In addition, these equations were developed for cultivars which no longer are cultivated in Brazil.
The foliar diseases incidences and severities were higher in the 2010 than in 2009 growing season (Figures 1 and 2) mainly in stages GS 45 (Full-boot, boot above ligule of $2^{\text {nd }}$ last leaf) and GS 56 (60\% of spikes visible) (Figures 1A and $1 \mathrm{~B}$ ). This result may be attributed to the more severe levels of powdery mildew in these plant GS, which was favored by the low rainfall during this period. Powdery mildew reduces the active foliar photosynthetic area by reducing of light absorption 


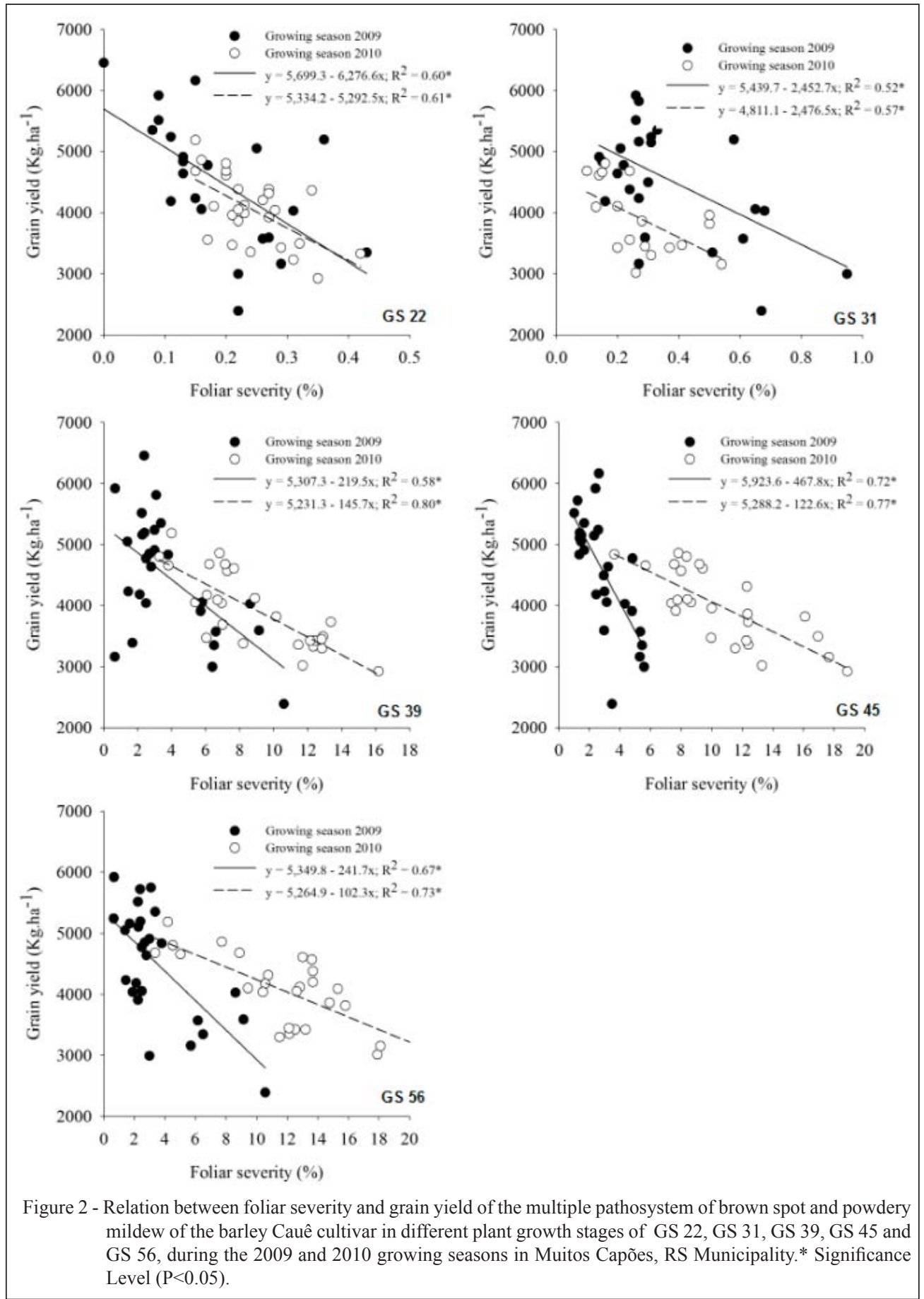

and consequently plant photoassimilation conversion, hindering the formation and grain filling (MATHRE, 1997; CZEMBOR, 2002). FUNCK et al. (2009) showed a low dry matter weight of wheat at vegetative dough growth stage in growing seasons with powdery mildew predominance.

The DFE of GS 22 showed the largest damage coefficient (Figures 1A and 2A) in both growing season, corroborating with BOHATCHUK et al. (2008) and REIS et al. (2008) wheat and oat data, respectively. The authors indicated that early disease onset in winter cereal in Southern Brazil has an impact on the grain yield, due to interference with the grain number per $\mathrm{m}^{2}$, which is determined by the tiller development (COOK et al., 1999). However, NERBASS et al. (2010), studying the same multiple 
pathosystem in oat, showed that the greatest damage occurs at the flowering (anthesis) stage, rather than tillering. Foliar incidence and severity are parameters used for diseases quantifications. Incidence is an objective variable while severity a subjective variable. However, both are correlated and incidence can be used to estimate severity and vice-verse. The relation between foliar incidences and severities was higher at the beginning of epidemics and, as the diseases develop, this relation becomes lower because the diseases were occurred over most of the leaves while the severities were still variable. Therefore, in the early epidemics stages the incidences and severities increased until all leaves were infected and for this point on the increase of diseases intensities occurred only by severities. The incidences were useful to evaluate the diseases when the epidemics were still in the early stages and in this situation, can be correlated with the severity.

For each $1 \%$ of foliar incidence, the economic damage threshold (EDT) for the multiple pathosystem of brown spot and powdery mildew generated a variable damage coefficient between $29.48 \mathrm{~kg} \mathrm{ha}^{-1}$ and $100.08 \mathrm{~kg} \mathrm{ha}^{-1}$ (2009 growing season) and between 36.08 and $113.57 \mathrm{~kg} \mathrm{ha}^{-1}$ (2010 growing season) of the grain yield (Figure 1 and 2). For each $1 \%$ of foliar severity, the damage coefficient was between $219.5 \mathrm{~kg} \mathrm{ha}^{-1}$ and $6,276.6 \mathrm{~kg} \mathrm{ha}^{-1}(2009$ growing season) and between 102.3 and $5,292.5 \mathrm{~kg}$ $\mathrm{ha}^{-1}$ (2010 growing season) of the grain yield (Figures 1 and 2). The damage coefficient obtained for different GS was used to calculate the EDT according to REIS et al. (2001). The EDT may be an useful criterion to indicate the moment for the fungicides applications to control the diseases. An example of such EDT calculation can be found in REIS \& CASA (2007), where, based on these relationships, a barley field with an estimated fungicide control cost of US\$ 48.00 ha $^{-1}$ (COOPERATIVA AGRÁRIA/ENTRE RIOS, 2012), barley commercial grain price US\$ $323.00 \mathrm{t}^{-1}$ (HGCA, 2014), 70\% fungicide efficiency and the damage coefficient obtained from the 2010 DFE (Figure 1) for GS 31 would have GY=4,751.8239.24 I with $\mathrm{R}^{2}=0.71$ ( $\mathrm{GY}=$ grain yield; $\mathrm{I}=$ incidence). In this case, for each $1 \%$ of disease incidence, the damage potential will be $39.24 \mathrm{~kg} \mathrm{ha}^{-1}$ or $0.03924 \mathrm{t}$. A field with $4,500 \mathrm{~kg} \mathrm{ha}^{-1}$ as its estimated yield would have a damage potential of $37.16 \mathrm{~kg} \mathrm{ha}^{-1}$ or $0.03716 \mathrm{t}$. Applying these values to the EDT formula would produce a foliar incidence of $2.8 \%$, indicating that fungicide applications for the control of brown spot and powdery mildew control must begin when the disease incidence reaches $2.8 \%$. The EDT considers the disease monitoring in the field. In the above example, the fungicide applications decisions only happens with $2.8 \%$ of brown spot and powdery mildew foliar incidence in the GS 31 . The EDT is a technical and economic criterion for technological decision-making, indicating the better moment for fungicide application. According to REIS \& CASA (2009), EDT is an integrated disease management tool to valorize the professional works in the field. The EDT value generally is not fixed and therefore varies according to the commercial price of barley grain, the fungicide control price and the fungicide efficiency. Therefore, it is important to continue research in different locations, growing seasons and cultivars to generate more DFE for barley foliar diseases to assist in fungicide decision making based on the EDT.

\section{CONCLUSION}

The relation between foliar incidence and severity by simultaneous occurrence of brown spot and powdery mildew and the barley BRS Cauê cultivar grain yield generated five incidence and severity DFE with their respective coefficients of determination $\left(\mathrm{R}^{2}\right)$, totaling 20 linear equations in 2009 and 2010 growing seasons in Southern Brazil. The incidence was useful to evaluate the diseases when the epidemics were still in the early stages and, in this situation, could be correlated with the severity. All DFE were significant and negative, where the increase of diseases symptoms reduced the grains yield according to the GS. DFE were used to calculate the EDT as a criterion to indicate the fungicide application moment to control the diseases in cultivars similar to 'BRS Cauê' in Southern Brazil.

\section{ACKNOWLEDGMENTS}

This research was financial supported by CNPq (The National Council for Scientific and Technological Development), CAPES (Coordination for the Improvement of Higher Level -or Education- Personnel) and FAPESC (Santa Catarina State Foundation for Scientific and Technological Development).

\section{REFERENCES}

AGRITEMPO. Sistema de Monitoramento Agrometereológico de Pesquisa, Rio Grande do Sul. Accessed: Sept. 28, 2012. Online. Available from: <http://www.agritempo.gov.br/agroclima/ pesquisaWeb?uf $=\mathrm{RS}>$.

HGCA. Agriculture and Hortiafculture Development Board. Accessed: Jan. 12, 2014. Online. Available from: <http://www.hgca. com/content.template/4/0/Corporate/Corporate/Corporate.mspx $>$.

BERGAMIN FILHO, A.; AMORIM, L. Doenças de plantas tropicais: epidemiologia e controle econômico. São Paulo: Ceres, 1996. 299p. 
BOHATCHUK, D.A. et al. Critical-point model to estimate damage caused by wheat leaf diseases in a multiple pathosystem. Tropical Plant Pathology, v.33, p.363-369, 2008. Available from: $<$ http://www. scielo.br/scielo.php?pid=S1982-56762008000500004\&script $=$ sci arttext>. Accessed: Nov. 25, 2012. doi: 10.1590/S198256762008000500004

CASA, R.T. et al. Critério: limiar de dano econômico (LDE) e quantificação de danos. In: BOLLER, V. Critérios indicadores do momento para aplicação de fungicidas visando ao controle de doenças em soja e trigo. Passo Fundo: Aldeia Norte, 2009. p.73-91.

COMPANHIA NACIONAL DE ABASTECIMENTO (CONAB). Acompanhamento de safra brasileira: oitavo levantamento maio 2012. Accessed: May 03, 2012. Online. Available from: <http://www.conab.gov.br/OlalaCMS/uploads/ arquivos/12_05_10_08_49_52_boletim_maio_2012.pdf $>$.

COOK, R.J. et al. Effects of fungicide spray timing on winter wheat disease control. Plant Pathology, v.48, p.33-50, 1999. Available from: <http://onlinelibrary.wiley.com/doi/10.1046 j.1365-3059.1999.00319.x/pdf>. Accessed: Dec. 04, 2012. doi: 10.1046/j.1365-3059.1999.00319.x.

CZEMBOR, J.H. Resistance to powdery mildew in selections from Moroccan barley landraces. Euphytica, v.125, p.397-409, 2002. Available from: $<$ http://link.springer.com/article/10.1023\% 2FA\%3A1016061508160?LI=true\#>. Accessed: Dec. 05, 2012.

EMPRESA BRASILEIRA DE PESQUISA AGROPECUÁRIA (EMBRAPA). Centro Nacional de Pesquisa de Solos. Sistema brasileiro de classificação de solos. Rio de Janeiro, 1999. 412p. Accessed: Dec. 05, 2012. Online. Available from: $<$ http://orton. catie.ac.cr/cgi-bin/wxis.exe/?IsisScript $=$ ACERVO. $x$ is\&method $=p$ ost $\&$ formato $=2 \&$ cantidad $=1 \&$ expresion $=\mathrm{mfn}=057212>$.

FUNCK, G. et al. Leaf diseases, healthy green area and kernel weight in different wheat cultivars. Revista Brasileira de Ciências Agrárias, v.4, p.03-10, 2009. Available from: <http:// agraria.pro.br/sistema/index.php?journal=agraria\&page $=$ article $\&$ op=viewFile \&path $\% 5 B \% 5 \mathrm{D}=10.5039 \% 2$ Frbca. $2009.190 \&$ path $\%$ $5 \mathrm{~B} \% 5 \mathrm{D}=267>$. Accessed: Dec. 05, 2012.

LENZ, G. et al. Disease severity and green leaf area maintenance depending on the application of micronutrients and fungicides in wheat. Summa Phytopathologica, v.37, p.119-124, 2011 Available from: <http://www.scielo.br/scielo.php?pid=S010054052011000200006\&script $=\mathrm{sci}$ arttext $>$. Accessed: Dec. 05 , 2012. doi: $10.1590 / \mathrm{S} 0100-54052011000200006$.

JAMES, W.C. An illustrated series of assessment keys for plant diseases, their preparation and usage. Canadian Plant Disease, v.51, p.39-65, 1971. Available from: <http://phytopath.ca/ download/cpds-archive/vol51/CPDS Vol 51 No 2 (39-65)1971. pdf>. Accessed: Dec. 05, 2012.

KUMAR, J. et al. Bipolaris sorokiniana a cereal pathogen of global concern: cytological and molecular approaches towards better control. Molecular Plant Pathology, v.3, p.185-195, 2002. Available from: $<$ http://www.uni-giessen.de/fbr09/ipaz/abt phytopath/publika/PDF/MPP-3-(4)-2002.pdf>. Accessed: Dec. 05, 2012. doi: 10.1046/j.1364-3703.2002.00120.x.

MATRHE, D.E. Compedium of barley diseases. 2.ed. St. Paul Minnesota: APS, 1997. 120p.
MEUSSDOERFFER, F.G. A comprehensive history of beer brewing. In: EßLINGER, H.M. (Eds.). Handbook of brewing: processes, technology, markets. Weinheim: Wiley-Vch, 2009. p.1-42.

NERBASS JUNIOR, J.M. et al. Critical-point models to relate white oat yield and disease intensity of the multiple pathosystem leaf rust - helminthosporium blight. Ciência Rural, v.40, p.1-6, 2010. Available from: <http://www.scielo.br/scielo.php?pid=S0103$84782010000100001 \&$ script $=$ sci_arttext\&tlng $=\mathrm{ES}>$. Accessed: Dec. 05, 2012. doi: 10.1590/S0103-84782009005000228.

PICININI, E.C. et al. Impacto econômico do uso do fungicida propiconazole na cultura do trigo (Triticum aestivum). Fitopatologia Brasileira, v.21, p.362-368, 1996.

REIS, E.M. et al. Quantificação de danos associados com a mancha em rede causada por Drechslera teres. Fitopatologia Brasileira, v.24, p.320-328, 1999.

REIS, E.R et al. Effect of leaf rust on wheat grain yield. Fitopatologia Brasileira, v.25, p.67-71, 2000. Available from: $<$ http://www.cabdirect.org/abstracts/20013091589.html>. Accessed: Dec. 05, 2012.

REIS, E.M. et al. Diagnose, patometria e controle de doenças de cereais de inverno. Londrina: ES Comunicação, 2001. 56p.

REIS, E.M. et al. A critical-point model to estimate yield losses caused by powdery mildew in barley. Fitopatologia Brasileira, v.27, p.644-646, 2002. Available from: <http://www.scielo.br/pdf/ fb/v27n6/a16v27n6.pdf>. Accessed: Dec. 05, 2012. doi: 10.1590/ S0100-41582002000600016.

REIS, E.M.; CASA, R.T. Doenças dos cereais de inverno: diagnose, epidemiologia e controle. 2.ed. Lages: Graphel, 2007. 78p.

REIS, E.M. et al. Critical-Point yield model to estimate yield damage caused by Cercospora zea-maydis in corn. Fitopatologia Brasileira, v.32, p.110-113, 2007. Available from: <http://www. scielo.br/scielo.php?pid=S0100-41582007000200003\&script=sci arttext>. Accessed: Dec. 05, 2012. doi: 10.1590/S010041582007000200003 .

REIS, E.M. et al. Critical yield models to estimate the damage caused by leaf rust in white oat. Summa Phytopathologica, v.34, p.238-241, 2008. Available from: <http://www.scielo. br/scielo.php?pid $=$ S0100-54052008000300006\& script $=$ sci arttext $>$. Accessed on: Dec. 05, 2012. doi: 10.1590/S010054052008000300006

REUNIÃO NACIONAL DE PESQUISA DE CEVADA Indicações técnicas da cultura da cevada cervejeira nas safras 2011 e 2012. 2011. Passo Fundo: Embrapa Trigo, 2011. 75p.

TOMERLIN, J.R.; HOWELL, T.A. Distrain: a computer program for training people to estimate severity on cereal leaves. Plant Disease, v.72, p.455-459, 1998.

ZADOKS, J.C. et al. Decimal code for the growth stages of cereals. Weed Research, v.14, p.415-421, 1974. Available from: $<$ http://onlinelibrary.wiley.com/doi/10.1111/j.1365-3180.1974. tb01084.x/abstract>. Accessed: Dec. 05, 2012. doi: 10.1111/ j.1365-3180.1974.tb01084.x. 